\title{
Bridging the Gap: Indigenous Methods as Necessity to Heal Landscape and Enhance Cultural Identity
}

BRUNO MARQUES | ASHLEIGH HUNTER | KURT COLE

Victoria University of Wellington, New Zealand

\section{wetlands | indigenous methods | rongoā | landscape design | Wairarapa}

\begin{abstract}
New Zealand's landscape is an invaluable resource that is often taken for granted and undervalued in today's economy. Providing economic benefits alongside cultural identity results in a diminished landscape as the population expands and development sprawls. A shift in thinking is required to ensure the natural environment is protected for the future - a shift that acknowledges the amenity value of the land and the embodied indigenous knowledge.
\end{abstract}

This paper examines Lake Wairarapa, the third largest lake in the North Island of New Zealand located only $80 \mathrm{~km}$ northeast of the capital city Wellington. Historically the lake covered $210 \mathrm{~km}^{2}$ holding some of New Zealand's most significant wetland systems. Today the lake has shrunk to $78 \mathrm{~km}^{2}$. This significant drop in area is due to the introduction of farming including both agriculture and horticulture, which have also now become the primary sources of pollution. The rapid decline in the quality of the lake has resulted in a landscape in desperate need to be healed.

This paper explores how this threatened natural land can be used to motivate the design of a regenerating ecosystem that not only provides amenity value but also begins to mitigate the adverse effects of inevitable development. It trials the use of traditional indigenous Māori healing methods to restore the underlying ecological function that benefits the environment and the Greater Wellington Regional Green/Blue Infrastructure.

\section{Problem Statement}

Natural systems throughout New Zealand that remain unharmed are in decline. This started in early European settlement with the introduction of new resources and a mindset driven by economics. Pre-European New Zealand was a land of bog, marsh, and peatlands, resulting in the majority of the land cover being a large-scale wetland. Over the past century "90\% of these wetlands have been destroyed or significantly modified through draining and other anthropogenic activities" (Harmsworth 2002: 8) supported by governmental Acts that date back to 1908, in order to provide land for farming and built development.

Lake Wairarapa, historically the third largest lake in the North Island of New Zealand once held some of the country's most significant wetland systems. The combination of farming in both agriculture and horticulture has resulted in a loss of $37 \%$ of the lake area to industry - an area of $132 \mathrm{~km}^{2}$ (Figure 1). The addition of infrastructure such as stop banks, drains, and constant pumping stations combined with clearance for productive pasture are the primary sources of pollution and have significantly reduced the quality of the lake.

The region is home to two Māori tribes, Kahungunu ki Wairarapa and Rangitane o Wairarapa. These tribes were put into a difficult position during the settlement wars, and as a result they gifted the lake to the British Crown. The lake and the surrounding land historically provided for the people through means of transport, food, medicine, material and it also held deep spiritual connections. Following the change of ownership, the lake deteriorated to its current condition. This paper explores how traditional healing concepts practiced by Māori can aid landscape architecture and find more resilient alternatives to the heavily engineered infrastructural solutions enacted and proposed. In doing so, there is also the potential to heal the people. 


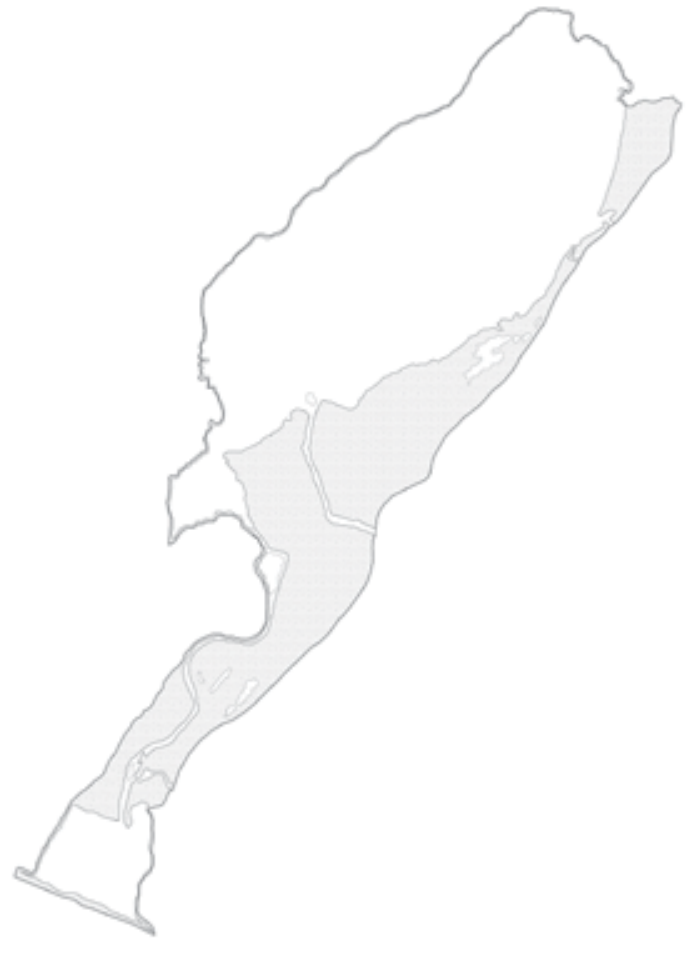

FIGURE 1. Historic (hatched) and current (white) area of Lake Wairarapa. Author: A Hunter

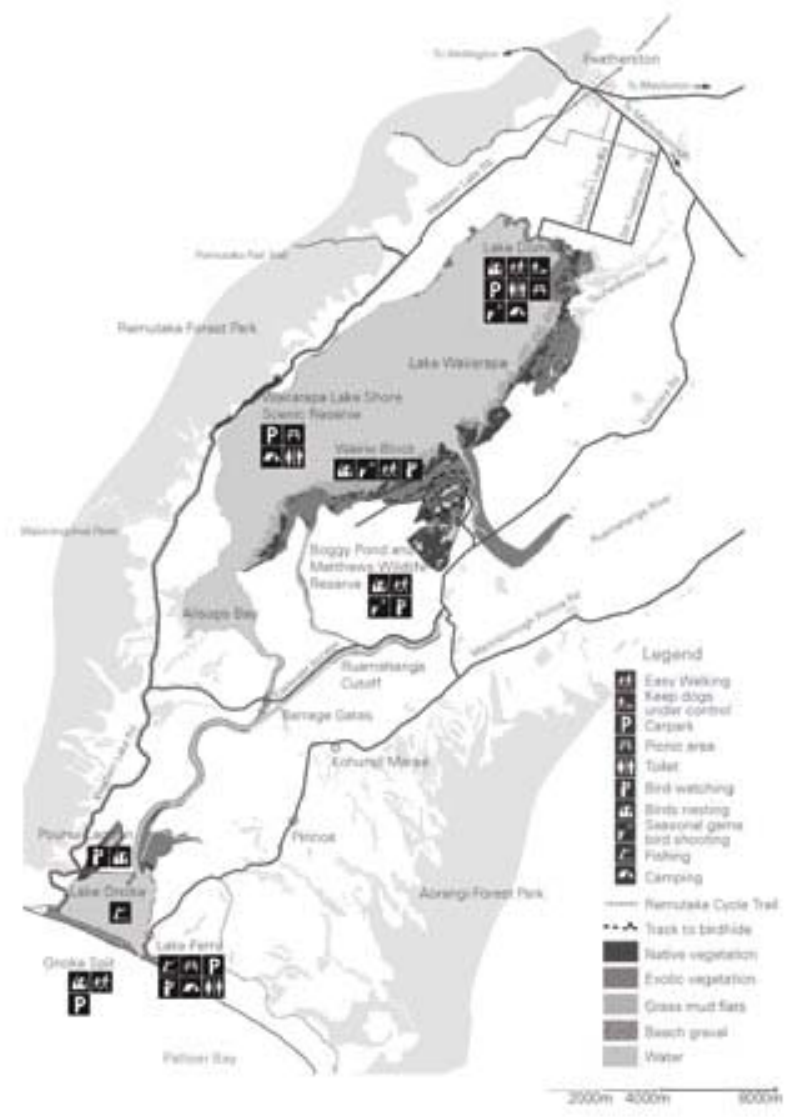

FIGURE 2. South Wairarapa region showing natural and built infrastructures.

Author: A Hunter

\section{South Wairarapa}

Lake Wairarapa sits beneath the Ruamahanga ranges. Currently the lake is approximately 2.5 meters at its deepest point, more than 3.5 meters shallower than in its recent past. The two main water sources that fuel the lake are the Ruamahanga and Tuaherenikau Rivers (Figure 2).

Public infrastructure has disturbed ecological tendencies occurring pre 1950's but has contributed to reduce the impact of flooding in the area. The implementation of a $4.2 \mathrm{~km}$ long and $500 \mathrm{~m}$ wide river diversion in the Ruamahanga River in a form of a channel has enhanced productivity through agriculture and horticulture but has also deeply damaged the wider ecosystem. In the last 60 years the communities living in the region have suffered equally, experiencing a decline in overall education and well-being; a reduction in the quality of their water quality and a loss of the aesthetic value of the waterways. As a consequence, people tend not to respect the presence and life of the waterways as they had in the past. Due to the development of the lower Wairarapa valley flood scheme and the introduction of a river diversion, much of the lake and surrounding wetlands have been drained or modified and areas of water have been diverted to allow for a more controlled and managed environment. The natural systems no longer provide a mean of recreation, food, medicine, transport and so forth.

\section{Healing the Landscape}

Over the years following European colonisation, there have been numerous arguments around the increasing decline in awareness of cultural landscapes and practice of traditional Māori methods. The use of chemicals, technologies and land modification have taken its toll on natural practices. This not only affected the land, but also the people who witness and experience the changes (Figure 3).

Rongoā Maori is a traditional healing system that focuses on the oral transmission of knowledge, diversity of practice and the spiritual dimension of health and wellbeing. It encompasses herbal remedies, physical therapies and spiritual healing (Ahuriri-Driscoll 2008).

The idea of 'healing' is widely understood as a method primarily applied to a person; however this same method can be adapted to the land "since the land should be our first patient" (McGowan 2009). Rongoā is the term for the traditional Māori methods practiced by tohunga (experts, healers); it is a way of living through the weaving of nature, wairua (spirit) and people to form a realm of well-being. This holistic indigenous method is about understanding the land and what it provides, requiring one to have a greater knowledge of the condition of the land, thereby gaining an understanding of what is causing the problem and facilitating a design solution. 


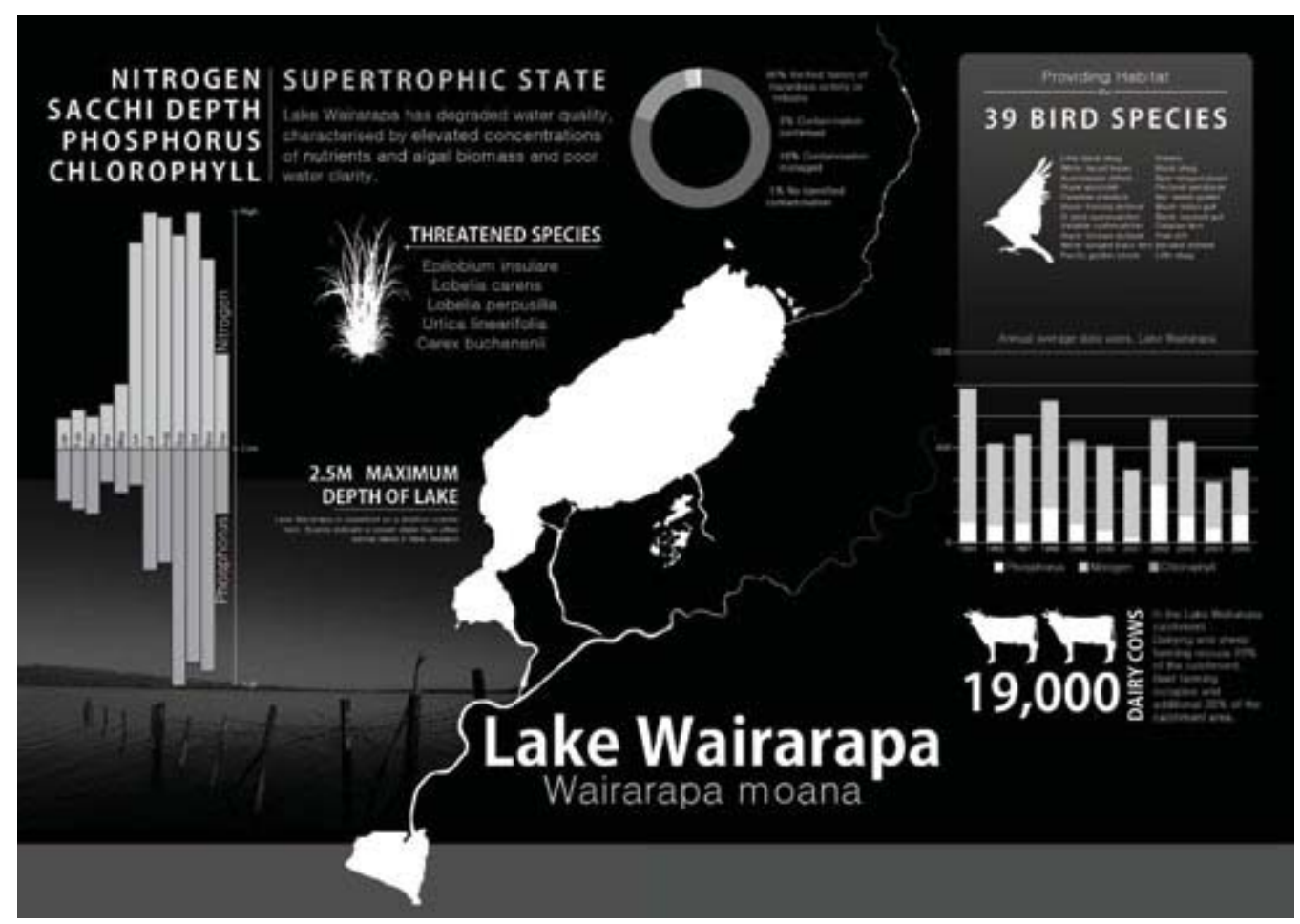

FIGURE 3. Infographic of Lake Wairarapa. Author: K Cole.

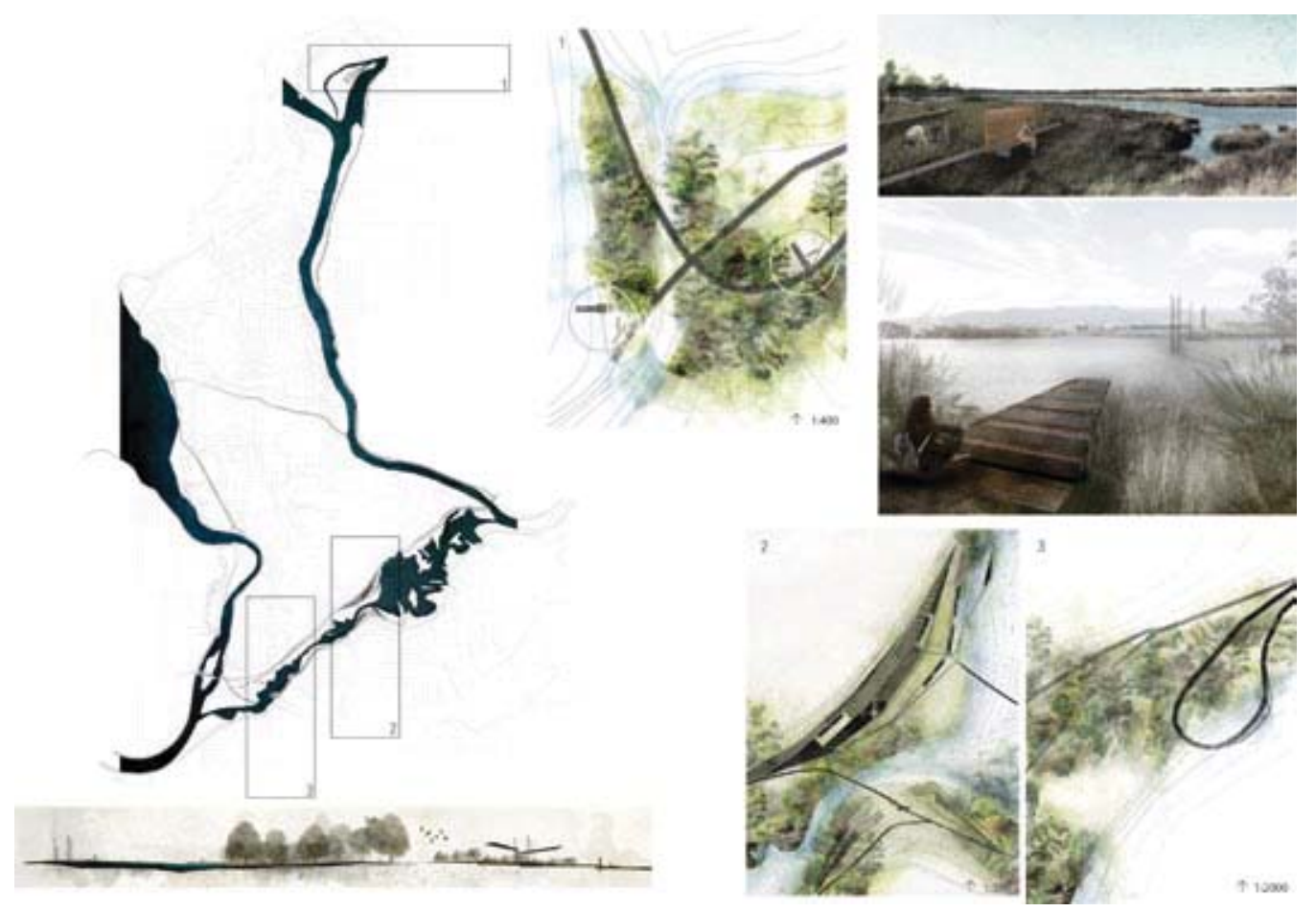

FIGURE 4. Three design proposals for the selected sites along the lake's shore and river diversion. These design solutions bring together the concepts of Rongoā as well as water and storage, material production and restoration, food production and recreation. Author: A. Hunter.

Rongoā Māori can be an important tool for restoration by incorporating the deeper meanings of cultural values and methods to re-connect and re-develop a way of designing for the land and people. "Restoration not only of the environment but of the people” (McGowan 2009: 32).

\section{Design Strategies}

Designing with the concepts of Rongoā and weaving them through the principles of landscape architecture, then developing and testing the design through a series of iterations can lead to a more sustainable approach (Figure 4). This strategy allows the intertwining of natural systems that incorporate native vegetation; with opportunities to re-educate people 


\begin{tabular}{|c|c|c|}
\hline Principle & Attribute & Application \\
\hline COHNECTION & 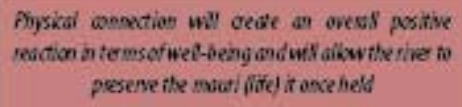 & 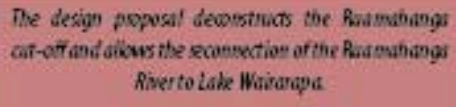 \\
\hline DIVERSION & 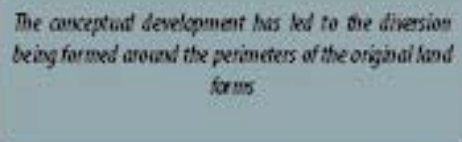 & 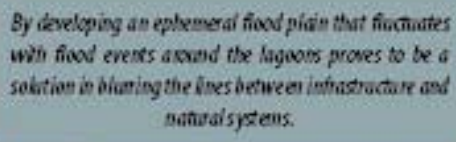 \\
\hline WETLANDS & 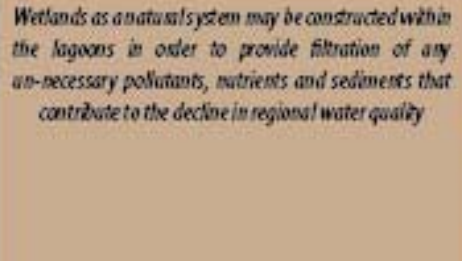 & 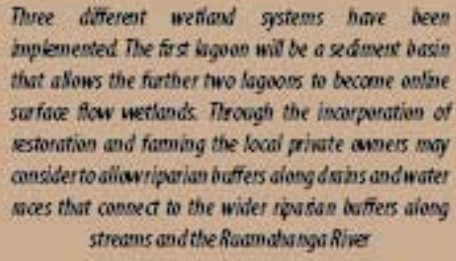 \\
\hline ROHGOA & 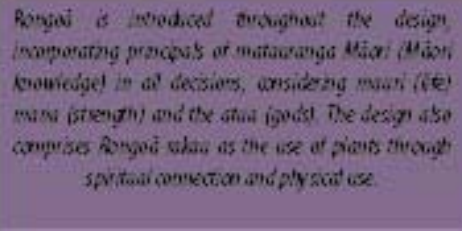 & 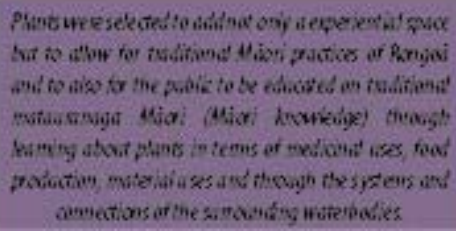 \\
\hline
\end{tabular}

TABLE 1. Design principles established with the typologies. Each design principle is explained in terms of attributes and design application.

on the significance of cultural landscape, hereby increasing diversity, and healing both the land and the psychic damage to the people through the process of restoring a damaged environment.

To test this proposition, this study has explored the softening of the hard infrastructure, with natural systems and cultural practices. The river diversion is a place of hard infrastructure and it is here where the analysis led to the establishment of three different typologies making it something more than a simple restoration project. These typologies surround the uses of water and water storage, material production and restoration, as well as food production and restoration as summarised in Table 1 . To be a viable option and taking into consideration the site's location amongst productive agricultural lands, un-doing the historic linear approach must be balanced with the needs for beneficial economic growth.

\section{Conclusion}

This study has developed and tested an approach whereby cultural concepts and practices aid landscape architecture in the creation of new/old methods for healing. They reinstate the connections between man and his environment as well as create experience and engagement for the public with indigenous knowledge. This strategy also allows the infrastructure to become one with the natural systems to create a more sustainable environment, providing ecological and economic benefits. The process involves the shift of current thinking to consider landscape as a complex and valuable asset that adds to our cultural identity and spiritual well-being as well as our economic benefit.

\section{References}

Ahuriri-Driscoll, A., New Zealand. Ministry of Health, Institute of Environmental Science Research, \& Te Whare Wānanga o Awanuiārangi. (2008). The Future of Rongoā Māori Wellbeing and Sustainability : A Summary / Annabel Ahuriri-Driscoll ... [et Al.].

Harmsworth, G., New Zealand. Ministry of Environment, \& Landcare Research (2002). Coordinated monitoring of New Zealand wetlands Phase 2, Goal 2: Maori environmental performance indicators for wetland condition and trend. Available at http://www.landcareresearch.co.nz/publications/ researchpubs/harmsworth_monitoring_wetlands.pdf.

McGowan, R. (2009). Rongoa Maori: a practical guide to traditional Maori medicine. Tauranga, New Zealand: Rob McGowan. 